\title{
Analiza fazy przygotowawczej rozbiórki obiektu budowlanego
}

\author{
Anna Sobotka ${ }^{1}$, Joanna Sagan ${ }^{2}$ \\ ${ }^{1}$ Katedra Geomechaniki, Budownictwa i Geotechniki, Wydziat Górnictwa i Geoinżynierii, \\ AGH Akademia Górniczo-Hutnicza w Krakowie, e-mail: sobotka@agh.edu.pl \\ ${ }^{2}$ studentka studiów III stopnia kier. budownictwo, Wydziat Górnictwa i Geoinżynierii, \\ AGH Akademia Górniczo-Hutnicza w Krakowie, e-mai: czaja.jahanna@gmail.com
}

Streszczenie: Rozbiórka może stanowić samodzielne przedsięwzięcie budowlane lub jego etap początkowy. Jak każde przedsięwzięcie składa się $\mathrm{z}$ wielu etapów - w tym zaplanowania i przygotowania robót rozbiórkowych. W artykule przeprowadzono analizę działań w fazie przygotowawczej rozbiórki, bazując na wymaganiach aktów prawnych, w tym Prawa budowlanego.

Słowa kluczowe: obiekt budowlany, rozbiórki, przepisy prawne, decyzje.

\section{Wprowadzenie}

Budowa nowego obiektu jak również rozbiórka już istniejącego, stanowi przedsięwzięcie budowlane. Jej wykonanie wymaga czasu i ponoszenia kosztów, stąd można określić ją mianem procesu inwestycyjno-budowlanego, składającego się z faz, które obejmują wiele etapów i zadań, począwszy od wstępnego planowania, terenowych prac badawczych, poprzez projektowanie, postępowanie administracyjne, prace przygotowawcze do rozpoczęcia rozbiórki, właściwe roboty rozbiórkowe, prace porządkowe, kończąc na odbiorze. Często jest jednym z etapów nowej inwestycji.

Zwykle rozbiórki obiektów budowlanych, wykonywane są w trudnych realizacyjnych warunkach - gęstej zabudowy, przy odbywającym się ruchu ulicznym itd. Realizacja rozbiórek jest także skomplikowanym, trudnym przedsięwzięciem pod względem technicznym, organizacyjnym - w tym logistycznym a w szczególności pod względem zapewnienia bezpieczeństwa. Ich wykonywanie wymaga od wykonawców posiadania dużej wiedzy i doświadczenia popartego posiadaniem uprawnień budowlanych $\mathrm{w}$ odpowiedniej specjalności. Przedsiębiorstwa trudniące się robotami rozbiórkowymi zwykle kompleksowo zajmują się realizacją przedsięwzięcia - prowadząc etap przygotowania inwestycji, badania stanu technicznego, przygotowanie projektu robót rozbiórkowych, ich harmonogramowanie, wykonanie, zagospodarowanie odpadów budowlanych, itp. - w zależności od warunków umowy. Decyzje związane z rozbiórkami budynków poprzedzone powinny być szczególnie starannymi działaniami przygotowawczymi. Jest oczywistym, że dobrze przygotowane i zaplanowane przedsięwzięcie kończy się zwykle osiągnięciem zamierzonych celów.

\section{Zadania w fazie przygotowawczej rozbiórki obiektu}

Powodów, dla których zapada decyzja o rozbiórce obiektu może być wiele:

- nieużytkowany lub niewykończony obiekt budowlany (za wyjątkiem obiektów wpisanych do rejestru zabytków), 
- w miejscu istniejącego obiektu budowlanego, ma powstać obiekt o innym przeznaczeniu lub obiekt nowocześniejszy,

- jako skutek samowoli budowlanej,

- likwidacja zakładów przemysłowych, infrastruktury transportowej (dobrym tego przykładem są obecnie masowe (tysiące obiektów) rozbiórki infrastruktury kolejowej PKP obejmującej budynki, wiadukty, perony, torowiska itp.,

- obiekt budowlany, nie spełnia swoich funkcji z różnych przyczyn (miernego standardu, braku zapotrzebowania na użytkowanie),

- inne.

Przygotowanie oraz przedłożenie dokumentacji jest ważnym zadaniem przygotowawczym. Przed złożeniem pełnej dokumentacji, należy dokonać prawidłowej klasyfikacji obiektu, oraz sposobu prowadzenia robót rozbiórkowych, a także uwzględnić przyczyny rozbiórki, gdyż składowe te będą warunkowały tryb postępowania administracyjnego (tab. 1).

Tabela 1. Tryby postępowania administracyjnego

\begin{tabular}{|c|c|c|}
\hline \multicolumn{3}{|c|}{ Tryb postępowania administracyjnego } \\
\hline brak & Zgłoszenie & Pozwolenie na rozbiórkę \\
\hline $\begin{array}{l}\text { Obiekty i urządze- } \\
\text { nia budowlane, na } \\
\text { budowę, których } \\
\text { nie jest wymagane } \\
\text { pozwolenie na } \\
\text { budowę, jeżeli nie } \\
\text { podlegają ochronie } \\
\text { jako zabytki }\end{array}$ & $\begin{array}{l}\text { Budynki i budowle } \\
\text { o wysokości poniżej } \\
8 \mathrm{~m} \text {, jeżeli ich odle- } \\
\text { głość od granicy } \\
\text { działki jest nie mniej- } \\
\text { sza niż połowa wyso- } \\
\text { kości }\end{array}$ & $\begin{array}{l}\text { Obiekty wpisane do rejestru zabytków, } \\
\text { Obiekty budowlane o wysokości powyżej } 8 \mathrm{~m} \text {, w tym: } \\
\text { rozbierane metodami tradycyjnymi ręcznie lub przy użyciu } \\
\text { urządzeń do mechanicznego kruszenia konstrukcji do } \\
\text { wysokości } 20 \mathrm{~m} \text {, } \\
\text { Rozbiórka z użyciem materiałów wybuchowych konstruk- } \\
\text { cji powyżej } 20 \mathrm{~m} \text {, } \\
\text { Rozbiórka obiektu może wpłynąć na pogorszenie stosun- } \\
\text { ków wodnych, sanitarnych oraz środowiska. }\end{array}$ \\
\hline
\end{tabular}

Zarówno w przypadku obiektów przeznaczonych do likwidacji z zastosowaniem materiałów wybuchowych jak i w przypadku rozbiórek wynikłych z uszkodzeń spowodowanych działaniem żywiołów, obowiązują dodatkowe, odrębne przepisy. Dokumenty, jakie należy przedłożyć celem zgłoszenia lub wnioskowania o pozwolenie na rozbiórkę są określone w przepisach prawa [1].

Zgodnie z Prawem budowlanym (art. 67) zarówno nieużytkowane obiekty budowlane jak i obiekty niewykończone, które nie nadają się do remontu, odbudowy lub wykończenia, zostają przeznaczone do rozbiórki w drodze nakazu wydanego przez Nadzór Budowlany. W przypadku, gdy w wyniku złego stanu technicznego obiektu, dochodzi do zagrożenia życia lub mienia, wówczas należy niezwłocznie przystąpić do prac rozbiórkowych z jednoczesnym dopełnieniem spraw urzędowych. Przepisów tych nie stosuje się do obiektów wpisanych do rejestru zabytków. Decyzja o nakazie rozbiórki wydana przez nadzór budowlany, obliguje właściciela lub zarządcę obiektu do zorganizowania robót rozbiórkowych oraz uporządkowania terenu w wyznaczonym terminie. Etapy i zadania, poprzedzające rozbiórkę przedstawione są w sposób uporządkowany na rysunku 1. Pola zaciemnione wskazują ścieżkę postępowania prowadzonego przez organy nadzoru budowlanego, pola jasne - przez organy administracji architektoniczno-budowlanej. 


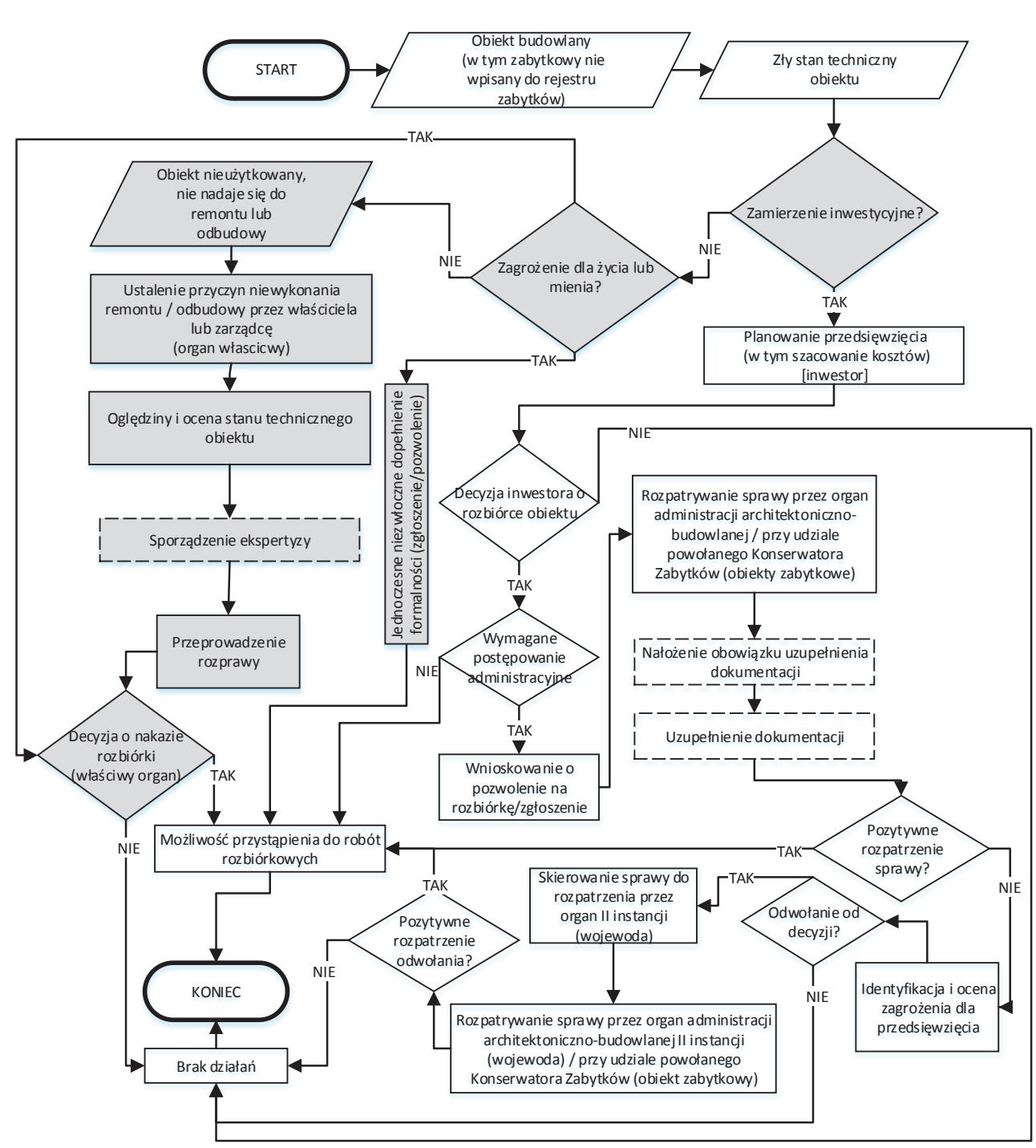

Rys. 1. Model postępowania poprzedzającego rozpoczęcie robót rozbiórkowych dla obiektów budowlanych niewpisanych do rejestru zabytków

Jednym z istotnych, często wymaganych a kłopotliwych dokumentów jest projekt rozbiórki. Najważniejszą jego częścią jest opis techniczny oraz rzuty i przekroje obiektu. Powinien on zawierać również wytyczne dotyczące kolejności i sposobu przeprowadzenia robót, organizacji zespołów roboczych, warunków bhp itp. Praktyka pokazuje, że projekt taki nie jest opracowaniem docelowym, gdyż wraz z postępem robót następują istotne jego modyfikacje, ze względu na napotkane np. rozwiązania konstrukcyjne, niezidentyfikowane przed ich odsłonięciem w kolejnych etapach rozbiórki.

Organami właściwymi do wydawania decyzji w sprawie rozbiórek obiektów budowlanych są organy administracji architektoniczno-budowlanej lub nadzoru budowlanego odpowiednio do przyznanych im Prawem budowlanym właściwości rzeczowych. 
W przypadku zgłoszenia, do robót rozbiórkowych przystąpić można, gdy organ właściwy, w drodze decyzji, nie wniesie sprzeciwu w terminie do $30 \mathrm{dni}$ od dnia doręczenia zgłoszenia.

Z kolei, pozwolenie na rozbiórkę zostaje wydane niezwłocznie jednak nie później niż w terminie 65 dni od dnia złożenia wniosku (przekroczenie wskazanego terminu powoduje nałożenie kar finansowych na właściwy organ). Od decyzji przysługuje odwołanie do organu wyższego szczebla a więc do wojewody. Odwołanie należy złożyć do 14 dni od dnia doręczenia decyzji, za pośrednictwem organu, który decyzje wydał.

W przypadku, gdy zły stan techniczny obiektu stanowi zagrożenie, lub jest nieużytkowany i nie nadaje się do remontu, może wystąpić okoliczność nakazu rozbiórki. W takich okolicznościach właściwy organ nadzoru budowlanego wydaje decyzję nakazującą właścicielowi lub zarządcy rozbiórkę tego obiektu i uporządkowanie terenu oraz określającą terminy przystąpienia do tych robót i ich zakończenia (Art. 67 ust. 1 [1]). Wówczas zgodnie $\mathrm{z}$ art. 2. rozporządzenia Ministra Infrastruktury z dnia 30.08.2004 r. w sprawie warunków i trybu postępowania w sprawach rozbiórek nieużytkowanych lub niewykończonych budowlanych [2] właściwy organ jest zobligowany do:

- „Ustalenia przyczyn niewykonania przez właściciela lub zarządcę obiektu budowlanego obowiązku wyremontowania, odbudowy lub wykończenia obiektu,

- Dokonania oględzin i oceny stanu technicznego, a gdy zajdzie potrzeba, nakazuje sporządzenie ekspertyzy technicznej obiektu budowlanego,

- Przeprowadzenia rozprawy".

Oględziny oraz ocena stanu technicznego obiektu zwieńczone zostają opisem stanu technicznego, ustaleniem przyczyn powstałych uszkodzeń oraz zniszczeń obiektu, określony zostaje stan zagrożenia bezpieczeństwa ludzi lub mienia oraz zagrożenia dla środowiska i zdrowia ludzi. W przypadku obiektu niewykończonego, dodatkowo sporządzany zostaje opis stanu zaawansowania robót budowlanych. Do nakazu sporządzenia ekspertyzy technicznej obiektu budowlanego dochodzi, gdy podczas oględzin powstaną uzasadnione wątpliwości co do stanu technicznego obiektu [2]. Odpis sporządzonego protokołu oględzin zostaje dostarczony właścicielowi obiektu lub zarządcy, z wyznaczeniem terminu rozprawy. Na podstawie ww. ekspertyz oraz przeprowadzonej rozprawy organ wydaje decyzję o rozbiórce, z wyznaczeniem terminu rozpoczęcia i zakończenia prac rozbiórkowych oraz uporządkowania terenu.

W 2014 r. wykonano 2950 rozbiórek wynikłych z nakazów. Liczba rozbiórek w ostatnich latach spadła, w stosunku do roku 2011 i 2012 (rys. 3).

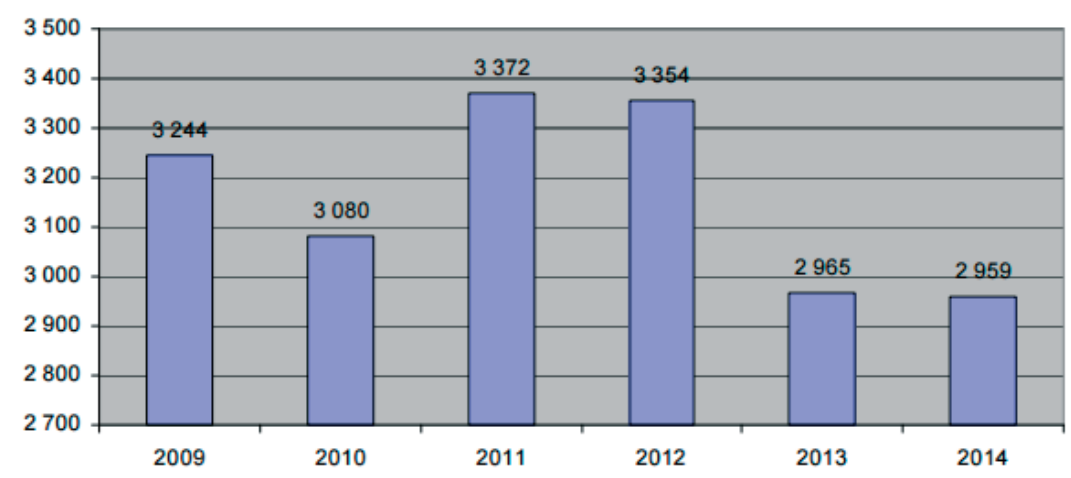

Rys. 3. Liczba wykonanych nakazów rozbiórek obiektów budowlanych w latach 2009-2014 [3] 
Powodem dużej liczby rozbiórek w latach 2011-2012 były decyzje o rozbiórkach w 2010 roku, spowodowanych powodzią. Procedura rozbiórki obiektów budowlanych zniszczonych lub uszkodzonych w wyniku działania żywiołów została uproszona w oparciu o Ustawę z dnia 11 sierpnia 2001 r.[4]. Ustawa ta może być stosowana w miejscowościach lub gminach ujętych w rozporządzeniu Prezesa Rady Ministrów, który na podstawie danych przekazanych przez wojewodów o rodzaju żywiołu oraz skutkach jego działania wskazuje obszary, w których znajdą zastosowanie jej przepisy na okres nie dłuższy niż 24 miesiące. Rozporządzenie stosuje się więc w przypadku powodzi, silnego wiatru, osunięcia ziemi, itp.. W przypadku wnioskowania o pozwolenie na rozbiórkę w takiej sytuacji nie stosuje się art. 32 $\div 34$ ust.1 i 3 Ustawy $\mathrm{Pb}$ [1]. Do wniosku o pozwolenie na rozbiórkę nie są wymagane pozwolenia, uzgodnienia lub opinie innych organów, gdyż przy właściwym organie administracji architektoniczno-budowlanej działa powołany Zespół Opiniowania Dokumentacji, który ocenia projekty architektoniczno-budowlane i zgłoszenia w zakresie określonym odrębnymi przepisami. Obiekty budowlane objęte, zgodnie z przepisami ustawy - Prawo budowlane [1], obowiązkiem uzyskania pozwolenia na budowę lub zgłoszenia a uszkodzone w wyniku działania żywiołu w stopniu powodującym konieczność ich rozbiórki, objęte są obowiązkiem dokonania zgłoszenia tych rozbiórek. Zgłoszenie rozbiórki dokonać należy przed rozpoczęciem robót budowlanych, które można rozpocząć, jeżeli w terminie 7 dni od doręczenia zawiadomienia właściwy organ administracji architektoniczno-budowlanej nie sprzeciwi się w drodze decyzji (art.8 ust.3 i 4 Ustawy z dnia 11 sierpnia 2001 [4]).

Organ administracji architektoniczno-budowlanej może nałożyć, w drodze decyzji, obowiązek uzyskania pozwolenia na wykonanie określonych robót budowlanych (rozbiórki) objętych obowiązkiem zgłoszenia, jeżeli ich realizacja może naruszać ustalenia miejscowego planu zagospodarowania przestrzennego, inne przepisy prawa lub spowodować:

1) zagrożenie bezpieczeństwa ludzi lub mienia,

2) pogorszenie stanu środowiska lub dóbr kultury,

3) pogorszenie warunków zdrowotno-sanitarnych,

4) wprowadzenie, utrwalenie albo zwiększenie ograniczeń lub uciążliwości dla terenów sąsiednich. (art.8 ust.2 Ustawy z dnia 11 sierpnia 2001 [4]).

Wśród dokumentów, związanych z prowadzeniem robót rozbiórkowych, które w razie potrzeby należy uzyskać, są pozwolenie na: wyłączenie pasów ruchu/chodnika na czas wykonywania prac, transport ciężkiego sprzętu, wyłączenie mediów, itp.

\section{Przyklad czasu trwania fazy przygotowawczej rozbiórki}

W zależności od rodzaju przedsięwzięcia budowlanego typu „rozbiórka budynku”, proces przygotowawczy obejmuje różne działania, które zwykle trwają długo i okres ten jest wydłużony o ustawowe okresy oczekiwania na decyzje. Niekompletna dokumentacja, lub zawierająca błędy, często wynika ze skomplikowanej sytuacji prawnej zamierzonej inwestycji. W tej sytuacji, dokumentacja wymaga uzupełnień, wydłużając okres wnioskowania. Z kolei błędy w dokumentacji mogą przesądzić o odrzuceniu wniosku. Dobrym przykładem jest faza wnioskowania o rozbiórkę budynku Tęczy w Krakowie.

Wniosek o udzielenie zgody na rozbiórkę wpłynął do urzędu 25.07.2012 r. W dniu 16.08.2012 inwestor uzupełnił braki formalne oraz doprecyzował i skorygował wniosek. Ze względu na wartość historyczną obiektu, budynek wymagał zgody na rozbiórkę Miejskiego Konserwatora Zabytków działającego w porozumieniu z Wojewódzkim Konserwatorem Zabytków, do których sprawa trafiła 30.08.2012 r. [5]. Z powodu dodatkowych wymagań konserwatorskich, nałożony został na inwestora obowiązek przedłożenia dodatkowych 
dokumentów - postanowienie wydano 1.10.2012 r. Wniosek został uzupełniony przez inwestora, i z datą 04.01.2013 r., po otrzymaniu zgody konserwatorskiej, organ wydał pozwolenie na rozbiórkę [5]. W tym przypadku, dobrze przygotowana, kompletna dokumentacja mogła zadecydować o szybszym rozpatrzeniu wniosku. Wtedy czas oczekiwania na rozpatrzenie decyzji skróciłby się o 60\%, do 65 dni (przyjmując maksymalny, ustawowy termin rozpatrzenia sprawy). Dużo czasu pochłonęło inwestorowi przygotowanie i przeprowadzenie przetargu na wykonanie robót rozbiórkowych obiektu. Faza przygotowawcza trwała 21 miesięcy. Natomiast wykonanie rozbiórki łącznie z opracowaniem projektu technicznego, ogrodzeniem i przygotowaniem terenu do pełnienia roli parkingu - niespełna 3 miesiące.

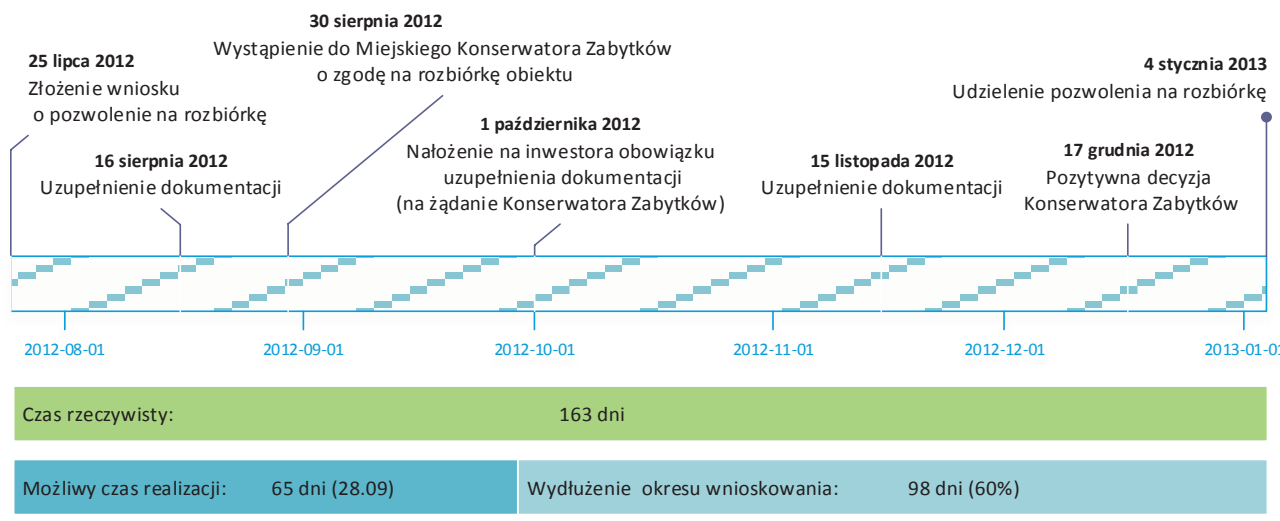

Rys. 4. Harmonogram wnioskowania o pozwolenie na rozbiórkę budynku Tęcza w Krakowie

\section{Podsumowanie}

Nie istnieje jednoznaczna ustawowa definicja rozbiórki, ale zgodnie z art. 3 ust. 7 ustawy z dnia 7 lipca 1994 roku Prawo budowlane [1], jest to jeden z rodzajów robót budowlanych, co z kolei rodzi pewne konsekwencje prawne związane z koniecznością stosowania odpowiednich procedur administracyjnych, a także podleganiu odpowiedzialności karnej w przypadku ich niedopełnienia (samowola budowlana). Rozbiórki obiektów dotyczą obiektów „starych” (technicznie, funkcjonalnie, ekonomicznie) często posiadających status obiektów zabytkowych, ale także budynków niewykończonych, jak i nowych - jako skutek samowoli budowlanej. W procesie inwestycyjno-budowlanym, faza przygotowawcza rozbiórki jest relatywnie długa. Okres oczekiwania na decyzję o pozwoleniu może ulegać wydłużeniu z powodu usterek formalnych, dlatego niezmiernie ważne jest przygotowanie kompletnej i poprawnej dokumentacji. Jakość prowadzenia pierwszej fazy przedsięwzięcia (sporządzanie wniosków, załączników, projektu rozbiórki jak i planu BIOZ itp.), będzie warunkowała stopień niepewności i ryzyka w fazie wykonawczej rozbiórki.

\section{Literatura}

1. Prawo budowlane, z późn. zm.( Dz. U. z 1994 r. Nr 89, poz. 414 Ustawa z dnia 7 lipca 1994 r.)

2. Rozporządzenie Ministra Infrastruktury z dnia 30 sierpnia 2004r. - w sprawie warunków i trybu postępowania w sprawach rozbiórek nieużytkowanych lub niewykończonych obiektów budowlanych (Dz. U. z 2004 r. Nr 198, poz. 2043).

3. Ruch Budowlany w 2014 roku, Główny Urząd Nadzoru Budowlanego, Warszawa, 2015. 
4. Ustawa z dnia 11.08.2001 r. o szczególnych zasadach odbudowy, remontów i rozbiórek obiektów budowlanych, zniszczonych lub uszkodzonych w wyniku działania żywiołu (Dz. U. z 2001 r. Nr 84, poz. 906 z późn. zm.).

5. Decyzja o pozwolenie na rozbiórkę nr 22/2013 wydana dla Akademii Górniczo-Hutniczej im. St. Staszica w Krakowie, z dnia 04.01.2013.

\title{
Analysis of phase preparatory demolition of a building
}

\author{
Anna Sobotka ${ }^{1}$, Joanna Sagan ${ }^{2}$ \\ ${ }^{1}$ Department of Geomechanics, Civil Engineering and Geotechnics, \\ Faculty of Mining and Geoengineering, AGH University of Science and Technology in Cracow, \\ e-mail:sobotka@agh.edu.pl \\ 2 student of III degree studies, course construction, Faculty of Mining and Geoengineering, \\ AGH University of Science and Technology in Cracow, e-mai:czaja.jahanna@gmail.com
}

\begin{abstract}
Demolition can be a stand-alone construction project or its initial phase. As ach project consists of several stages, including the planning and preparation of demolition. In the paper the analysis of activities in the preparatory phase of the demolition, based on the requirements of legal acts, including the Construction Law.
\end{abstract}

Keywords: building, demolition, law, decisions. 
